\title{
INFLUENCE OF STUDYING IN HIGHER EDUCATIONAL ESTABLISHMENT ON STUDENTS' HARMFUL COMPUTER HABITS
}

\author{
Kudryavtsev M.D. ${ }^{1,2,3}$, Kramida I.E. ${ }^{2}$, Iermakov S.S. ${ }^{4}$ \\ ${ }^{1}$ Siberian Federal University, Russia \\ ${ }^{2}$ Siberian State Aerospace University, Russia \\ ${ }^{3}$ Krasnoyarsk State Pedagogical University named after V.P. Astafieva, Russia \\ ${ }^{4}$ Kazimierz Wielki University in Bydgoszcz, Poland
}

\begin{abstract}
Purpose: to determine influence of educational process on prevalence of students' harmful computer habits. Material: in the research $1^{\text {st }}-3^{\text {rd }}$ year students ( 803 boys and 596 girls) participated. All they specialized in discipline "Physical culture". The students had no health disorders. Results: it was found that in average students have 2 computer habits everyone. The most probable and dangerous in respect to addicting are habits to use internet and computer games. Student, who has these habits, spends more than 4 hours a day for them. $33 \%$ of $1^{\text {st }}$ year boys and $16 \%$ of $1^{\text {st }}$ year girls spend more than 2 hours a day for computer games. $15-20 \%$ of boys and $25-30 \%$ of year girls waste more than 4 hours a day in internet. $10-15 \%$ of boys spend more than 4 hours a day for computer games. It is very probable that these students already have computer games' addiction. Conclusions: recent time dangerous tendency to watching anime has been appearing. Physical culture faculties and departments shall take additional measures on reduction of students' computer addictions. Teachers of all disciplines shall organize educational process with the help of electronic resources so that not to provoke progressing of students' computer habits.
\end{abstract}

Key words: students, boys, girls, computer habits, internet, computer games, physical culture, healthy life style.

\section{Introduction}

Perfection of computer technologies for students' teaching served as turning point in development of modern higher education. It also qualitatively changed principle of many state educational establishments' operation. Recent time special attention has been paying to studies in the field of computer addiction. It implies studying psychological aspects of computer addiction by analogy with psychological aspects of drugs, alcohol and other "traditional" addictions. Such parallels are rather convenient from the point of scientific research of computer games' addiction. If to prove that all these addictions are equivalent it will be possible to project all scope of accumulated knowledge to problem of harmful computer habits, as well as work out adequate prophylaxis and treatment methods.

In this situation rather interesting seems to be understanding of computer games' practical uselessness. But students can not give up computer games completely. It witnesses about rather high computer games psychological addiction. Such games are used by students for entertainment in long time intervals in students' preparation for classes.

In this connection the problem of internet pathological usage, mentioned in foreign literature, is becoming still more urgent $[19,22]$. The so-called "internet-addiction" is meant. Psycho-therapists and companies, using internet in their operation were the first, who faced this problem. The officers of such companies acquired pathological desire to be in "on-line" mode. It resulted in reduction of officers' efficiency and possible companies' losses. It is assumed that Cyber Disorder (CD) will enter in international classification of usual and the most wide spread diseases DSM-V [23].

Dependence on computer games is considered to be one of main kinds of internet addiction among young people of student's age. To-day many scientists speak about internet addiction problem [7, 8, 22]. Recent years some researches of computer games' activity and Internet activity has been being fulfilled [20, 21]. Such researches are widely spreading throughout the world 17,18$]$.

At the same time study of human activity with computer and Internet has become still more demanded. Special attention is attracted by youth's game activity and harmful computer habits $[3,8,12]$.

(c) Kudryavtsev M.D., Kramida I.E.,

lermakov S.S., 2016

doi:10.15561/20755279.2016.0503 
It was found that at present time significance of physical culture in formation of student's general culture has been increasing in HEEs for the following:

- Resistance of young person to harmful computer habits $[12,13$;

- Student's enculturation in general human values and healthy life style [11, 14];

- Health strengthening of physically and psychically not formed young person of student's age [9];

- Prophylaxis of harmful habits [10,11];

- Stable healthy life style $[2,4,15]$.

In other work prevalence of $1^{\text {st }}$ year students' computer habits at the beginning of studying in HEE, was found [11]. That is why it is evident that it is necessary to study degree of students' computer habits' prevalence in $1^{\text {st }}-3^{\text {rd }}$ years of studying at HEE: to research, which habits are the most dangerous in respect of their progressing in addiction. Besides, it is necessary to introduce possible changes in physical education faculties and departments' educational process.

Computer addictions include three the most wide spread habits: internet search or contacts in social nets (beyond those, which are required for study, work or creative work); computer games; watching anime, mangy and etc.

The purpose of the research: to determine influence of educational process on prevalence of students' harmful computer habits and find out possibilities for reduction of students' computer addiction danger.

The tasks of the research are: analysis of computer habits' prevalence among students; formation of appropriate tasks for physical culture faculties and departments; working out recommendations for teachers for reduction of students' addictions and harmful habits.

\section{Material and methods}

Participants: in the research $1^{\text {st }}-3^{\text {rd }}$ year students of Krasnoyarsk participated. All they specialized in discipline "Physical culture" for main health group. In total they were 803 boys and 596 girls.

Organization of the research: we questioned the students at the end of academic year. The students were offered to point the quantity of hours a day, pent for main computer habits. We used recommendations for questioning and assessment of its results [13].

Statistical analysis included the following:

a) Calculation of percentage of boys and girls, who had no computer habits. Separately we calculated the quantity of students, who spent to computer-sitting certain time (less than one hour, 1-2, 2-4 and more than four hours a day). We marked out the group of students by sex and year of study as well as students, who had computer habits;

b) Calculation of average quantity of computer habits in boys and girls;

c) Calculation of average time, spent for certain habit;

d) Assessment of confidence by Student's t-criterion at significance level less than 0.05 .

The received data were processed with Microsoft Excel statistical programs. .

\section{Results}

We found two main contradictions. The first: between need in internet usage in modern educational process and absence of researches on influence of educational internet on emerging and strength of computer habits. With it we considered: significant time of computer sitting; students' unhealthy way of life. The second: between impossibility to reject computer usage in educational process and practical absence of prophylaxis measures against emerging of harmful computer habits, which would be realized by means of physical culture and sports.

The main results of students' questioning are given in table 1-3. We showed results of average time (hours a day) spent by boys (b) and girls ( $g$ ) of every year of study for computer games, calculation. Besides, we presented percentage of students, who had and had no computer habits. 
Table 1. Distribution of students by time (hours/day), spent for Internet

\begin{tabular}{|c|c|c|c|c|c|c|c|}
\hline $\begin{array}{l}\text { Year of study, } \\
\text { sex }\end{array}$ & $\mathbf{N}$ & $\begin{array}{l}\text { Average quantity } \\
\text { of hours/day }\end{array}$ & No, \% & $<1, \%$ & $1-2, \%$ & $2-4, \%$ & $>4, \%$ \\
\hline $1 b$ & 421 & $2,5 \pm 0,1$ & 2 & 19 & 33 & 26 & 21 \\
\hline $2 b$ & 191 & $2,2 \pm 0,1$ & 1 & 24 & 33 & 19 & 17 \\
\hline $3 b$ & 191 & $2.2 \pm 0.1$ & 1 & 24 & 39 & 19 & 17 \\
\hline $1 g$ & 279 & $3.1 \pm 0.1$ & 1 & 11 & 22 & 35 & 30 \\
\hline $2 b$ & 152 & $2.9 \pm 0.1$ & 1 & 10 & 30 & 34 & 25 \\
\hline $3 g$ & 165 & $3.0 \pm 0.1$ & 1 & 9 & 27 & 36 & 25 \\
\hline
\end{tabular}

Notes: $\mathrm{N}$ - total volume of sample; 1b, 2b, 3b, 1g, 2g, 3g - students-boys and students-girls, questioned at the end of $1^{\text {st }}, 2^{\text {nd }}$ and $3^{\text {rd }}$ years of study; "No" - students, who had no computer habits (i.e. who do not spend time for it).

Table 2. Distribution of students by time (hours/day), spent for computer games

\begin{tabular}{|c|c|c|c|c|c|c|c|}
\hline $\begin{array}{l}\text { Year of } \\
\text { study, sex }\end{array}$ & $\mathbf{N}$ & $\begin{array}{l}\text { Average } \\
\text { quantity of } \\
\text { hours/day }\end{array}$ & No, \% & $<1, \%$ & $1-2, \%$ & $2-4, \%$ & $>4, \%$ \\
\hline $1 b$ & $1.7 \pm 0.1$ & 15 & 28 & 29 & 16 & 12 & \\
\hline $2 b$ & $1.4 \pm 0.1$ & 20 & 32 & 23 & 16 & 8 & \\
\hline $3 b$ & $1.4 \pm 0.1$ & 20 & 32 & 23 & 16 & 8 & \\
\hline $1 g$ & $0.5 \pm 0.1$ & 59 & 27 & 7 & 3 & 4 & \\
\hline $2 g$ & $0.4 \pm 0.1$ & 60 & 29 & 5 & 3 & 1 & \\
\hline $3 g$ & $0.4 \pm 0.1$ & 62 & 27 & 6 & 4 & 1 & \\
\hline
\end{tabular}

Table 3. Distribution of students by time (hours/day), spent for watching anime

\begin{tabular}{|c|c|c|c|c|c|c|c|}
\hline $\begin{array}{l}\text { Year of } \\
\text { study, sex }\end{array}$ & $\mathbf{N}$ & $\begin{array}{l}\text { Average } \\
\text { quantity of } \\
\text { hours/day }\end{array}$ & No, \% & $<1, \%$ & $1-2, \%$ & $2-4, \%$ & $>4, \%$ \\
\hline $1 b$ & $0.4 \pm 0.1$ & 74 & 17 & 4 & 2 & 3 & \\
\hline $2 b$ & $0.3 \pm 0.1$ & 74 & 17 & 5 & 3 & 2 & \\
\hline $3 b$ & $0.3 \pm 0.1$ & 74 & 17 & 5 & 3 & 2 & \\
\hline $1 g$ & $0.3 \pm 0.1$ & 60 & 13 & 4 & 2 & 2 & \\
\hline $2 g$ & $0.3 \pm 0.1$ & 77 & 18 & 3 & 2 & 2 & \\
\hline $3 g$ & $0.2 \pm 0.1$ & 79 & 17 & 2 & 1 & 1 & \\
\hline
\end{tabular}

Notes: volumes of samples and legend in tables 2-3 are the same as in table 1.

If contact with computer lasts more than two hours a day without break it becomes dangerous for human health. If student spends more than four hours a day for computer habit - there is high probability of this habit's progressing in addiction.

The questioning of $1^{\text {st }}-3^{\text {rd }}$ year students at the end of academic year showed the following:

1. In average boys and girls have 2 computer habits every. The most probable is that ordinary student of any sex has addiction to internet and computer games. At the end of $1^{\text {st }}$ year student with two habits spend on them in total: boys $-4.6 \pm 0.2$ hours, girls $-4.5 \pm 0.2$ hours a day. At the end of second year the indicators are as follows: boys $-4.1 \pm 0.2$ hours and girls $-3.9 \pm 0.2$ hours. At the end of third year the indicators are following: boys -4.1 \pm 0.2 hours and girls $-4.0 \pm 0.2$ hours a day. Both in boys and girls total time losses for the most wide spread computer habits reduce in the course of studying (difference between data for $1^{\text {st }}$ and $2-3^{\text {rd }}$ years is significant). However, these indicators are too high. 
Thus, in period of study at HEE at $1^{\mathrm{s}-} 3^{\text {rd }}$ years "average-statistical" student has computer habits. Student spends much time suiting at computer and it does harm for his/her health. As far as boys and girls spend for computer habits about four hours a day computer addiction is rather probable.

2. In many students every of two the most wide spread computer habits (internet, computer games) takes more than two hours a day. Percentage of boys with two habits reduces with increasing of their study in HEE period (the difference of these data is significant for $1^{\text {st }}$ and $2^{\text {nd }}$ years' groups). Among girls we did not register significant reduction. The highest quantity of such students (boys and girls) is among those, who have habit to spend time in internet (beyond time required for study, work or creative work). In girls' groups this quantity is bigger than in boys' groups (difference is significant for every years of study). Among boys the quantity of such students reduces to the third year. But still it is too high. More than half of girls and more than one-third of boys spend for internet more than 2 hours a day.

We also found the quantity of students, who pay more than two hours a day for other computer habits. Their quantity is much lower than for the habit "to escape to internet".

The following students play computer games more than two hours a day: $33 \%$ boys and $16 \%$ girls of $1^{\text {st }}$ year (for other years of study this percentage for both sexes is much lower).

$5 \%$ or even less (of all years' and both sex students) spends more than 2 hours a day for watching anime or mangy. At the end of $1^{\text {st }}$ year $18 \%$ of students spend more than two hours for this habit. Percentage of boystudents does not depend on year of study. Among girls habit to watch anime (more than 2 hours a day) reduces only by the end of $3^{\text {rd }}$ year. Comparison of the received data with other data [12] shows that percentage of such students significantly increases among $1^{\text {st }}$ and $3^{\text {rd }}$ year boy-students and among $1^{\text {st }}$ and $2^{\text {nd }}$ year girl students. Soon this habit will become dangerous for students' health.

3. At present the most dangerous (in respect to addictions' emerging) are the following computer habits: a) to spend time in internet; b) computer games (for boys). Every fifth boy of $1^{\text {st }}$ year and sixth student of $2^{\text {nd }}$ or $3^{\text {rd }}$ year spend more than four hours in virtual reality as well as every third girl student of $1^{\text {st }}$ year and every forth girl student of $2^{\text {nd }}$ or $3^{\text {rd }}$ year. $15 \%$ of $1^{\text {st }}$ year boy-students play computer games more than four hours a day (approximately every seventh) and $10 \%$ of $2^{\text {nd }}$ or $3^{\text {rd }}$ year boy students (every tenth). It is very probable that in such students these habits already became addictions. These students can not give up these habits without assistance of surrounding people.

\section{Discussion}

The received results can be used for solution of tasks of students' health improvement with the help of timely correction and prophylaxis work. In this aspect main role shall be played by physical culture teachers. It is recommended to use classes of applied physical culture and elective courses. Modern means of physical culture and sports shall be used to achieve the following:

- Avoiding of spending too much time at computer;

- Formation of steady understanding that it is necessary to reasonably limit oneself in computer games;

- Development of value-meaningful sphere of own interests for own health preservation; actualization of personal growth for overcoming harmful computer addiction.

Medical specialists started to deal with harmful computer habits about 10 years ago. With every passing year this problem has been becoming still more acute. Children and adults play computer and telephone games, attend internet café and game clubs. Alongside with it, at present time there is a deficit of this problem's researches in respect to value meaningful approach.

By a number of reasons students are the main mass of internet users. Just this part of population has the highest risk of internet addiction. Permanent demand in information, high cognitive motivation and social activity alongside with deficit of time make main internet users from students.

The main reasons of harmful computer habits' emerging among students are:

- Frequent use internet services;

- Easiness of using internet opportunities;

- Simplicity of internet communication;

- Completeness and accessibility of internet information;

- Large list of entertainments and opportunities. 
Strength of harmful computer habit can be corrected by trainings in sport circles or at usual physical culture lessons. According to health related tasks of teachers' activity it is possible to facilitate more successful integration of person in modern society, releasing computer addiction by means of physical culture and sports.

For full interaction of teachers, scientists and medical specialists it is necessary to create:

- System of reasonable time spending in internet;

- Cultivation of students' informational culture in modern society;

- Detection of harmful computer habit's emerging in due time;

- Distraction of youth from harmful impact of вcomputer habit by different kinds of health related physical culture and sports.

In the base of physical culture academic classes there shall be educational competence: ability to use physical culture means and methods for ensuring perfect social and professional functioning. In our research we tried to find interconnection of the most important spheres of human activity. Inevitable character of the widest usage of computers in education requires their reasonable application in educational process. Modern sphere of health related physical culture classes with students shall minimize the damage for youth's health, caused by excessive usage of computers and internet, when fulfilling academic tasks in electronic form; when preparing different works, including diploma.

The scope and orientation of learning tasks point at demand in usage modern computer and internet. In this case the problem of health preservation becomes still more significant and important [6]. It is known that computer monitor is a source of weak electromagnetic radiation in low frequency and high frequency ranges, $\mathrm{X}$ rays; ultraviolet rays; infra-red rays and radiations of visible range [5].

It is necessary to study influence of education of emerging students' harmful computer habits as well as to study effectiveness of "physical culture" discipline educational aspect. It is necessary to use measures for prevention from prevalence of harmful computer habits in students [2, 4, and 14].

For prophylaxis work with students, having steady harmful computer habits it is necessary to apply different forms of physical culture: health related oriental systems (Chi-gun, U-shy and etc.), different martial arts, new and traditional kinds of sports $[2,4,14]$.

Creation of physical culture-sports' prophylaxis activity general strategy can serve for prevention from further growth of harmful computer habits. In researches of these problems it was found that information technologies' continuing intervention more and more deforms values of computer operators $[1,16]$. It is evident that informational technologies are continuing to develop and sometimes replace principally important elements of human activity. This causes transformation of most important personality's qualities. Special section of researches of informational technologies and human interaction is connected with computer addictions study. These addictions are interpreted as pathological desire of a person to work with computer and it results in appearing harmful computer habits [1].

\section{Conclusions}

1. Most of $1^{\text {st }}-3^{\text {rd }}$ year students have from one to three computer habits. They spend rather much time for it every day, which is dangerous for health. Especially a lot of time is spent by boys and it damages their physical and psychic health.

2. There is great danger of internet and computer games' addiction in students as well as computer addiction in general, independent on kind of work at computer.

3. Recent time there has appeared dangerous tendency to progressing anime-watching habit and it can soon result in addiction.

4. Physical culture faculties and departments shall take additional measures for health improvement of students' life style and weakening of harmful computer habits. Besides, it is necessary to reduce probability of these habits' emerging and danger of addictions. Great role shall be played by physical culture lessons and independent practicing of physical exercises.

5. Teachers shall do the best to change students' attitude to own health and life style. Besides, they shall cultivate students' positive attitude to reading, art and sports. Such approach will facilitate reduction of students' harmful computer habits probability. 
6. Teachers shall organize students' classes and independent work so that not to provoke growth of students' computer harmful habits.

The prospects of further researches imply study of data on harmful habits on personality's, family and social levels of students. Besides, it is necessary to study specificity of students' computer activity, who study on different specialties.

\section{Conflict of interests}

The authors declare that there is no conflict of interests.

\section{References:}

1. Babaeva IuD, Vojskunskij AE, Smyslova OV. Internet: vozdejstvie na lichnost' [Internet: influence on personality], Moscow: Mozhaysk-Terra; 2000. (in Russian)

2. Bliznevsky AA, Kudryavtsev MD, Iermakov SS, Jagiełł W. Formation of active-effective attitude of 12-13 years' judo athletes to sports functioning in competition period. Archives of Budo, 2016;12:100-107.

3. Vojskunskij AE. Psikhologiia i Internet [Psychology and Internet], Moscow: Acropolis; 2010. (in Russian)

4. Gaskov AV, Kuzmin AV, Kudryavtsev DM, Iermakov SS, Successfulness of general and special physical qualities' development on different stage of students-boxers' training. Physical Education of Students, 2016;1:4-11. doi:10.15561/20755279.2016.0101

5. Demirchoglian GG. Komp'iuter $i$ zdorov'e [Computer and health], Moscow: Lukomorye, MB Tempo, New Center; 1997. (in Russian)

6. Zhurakovskaia AL. Vliianie komp'iuternykh tekhnologij na zdorov'e pol'zovatelia [Influence of computer technologies on user's health]. Vestnik Orenburgskogo gosudarstvennogo universiteta, 2002;2:169-173. (in Russian)

7. Kliueva NV. Pedagogicheskaia psikhologiia [Pedagogic psychology], Moscow: Vlados-Press; 2003. (in Russian)

8. Young K. Internet addiction: symptoms, evaluation and treatment. In L. VandeCreek \& T. Jackson (Eds.). Innovations in Clinical Practice: A Source Book. 1999;17;19-31

9. Kozina Z L, Iermakov SS, Kuzmin VA, Kudryavtsev MD, Galimov GJ. Change of cortisol and insulin content in blood under influence of special workability recreation system for students with high motor functioning level. Research Journal of Pharmaceutical, Biological and Chemical Sciences, 2016;7(2):1068-1077.

10. Kopylov YuA, Jackowska LN, Kudryavtsev MD, Kuzmin VA, Tolstopyatov IA, Iermakov SS. The concept of structure and content of health related trainings for higher educational establishments' students. Physical Education of Students, 2015;5:23-30. doi:10.15561/20755279.2015.0504

11. Kramida IE. Monitornye vrednye privychki studentov-pervokursnikov [Monitor harmful habits of first year students]. Mezhdunarodnaia nauchno-prakticheskaia konferenciia "Social'naia rabota v profilaktike zloupotrebleniia narkoticheskimi sredstvami i reabilitacii narkozavisimykh”, Makhachkala [International scientific-practical conference "Social work in prophylaxis of drugs-taking and rehabilitation of drugaddicted" Makhachkala], Makhachkala: DSU Publ.; 2014. P. 113 - 119. (in Russian)

12. Kudryavtsev MD, Kramida IE, Osipov AIu. Vliianie monitornykh vrednykh privychek na zdorovyj obraz zhizni studentov [Influence of monitor harmful habits on healthy life style of students]. Teoriia i praktika fizicheskoj kul'tury, 2016;6:24-26. (in Russian)

13. Kudryavtsev MD, Kramida IE, Kuzmin VA, Iermakov SS, Cieslicka Miroslawa, Stankiewicz Blazej. Influence of study in hee on ubiquity and strength of students' computer gambling. Physical Education of Students, 2016;3:13-22. doi:10.15561/20755279.2016.0302

14. Kuzmin VA, Kopylov YA, Kudryavtsev MD, Tolstopyatov IA, Galimov GY, Ionova OM. Formation of professionally important qualities of students with weakened motor fitness using a health related and sportoriented training program. Journal of physical education and sport, 2016;16(1):136-145. doi:10.7752/jpes.2016.01023

15. Kuzmin VA, Kopylov YuA, Kudryavtsev MD, Galimov GY, Iermakov SS. Substantiation of effectiveness of trainings on health related methodic for students with weakened motor fitness. Physical Education of Students, 2015;6:43-49. doi:10.15561/20755279.2015.0606 
16. Shvedov GI, Druganova LP, Shaeva TV. Negativnye faktory vozdejstviia komp'iutera na zdorov'e cheloveka [Negative factors of computer influence on human health]. Nauchno-medicinskij vestnik Central'nogo Chernozem'ia, 2008;32:10-12. (in Russian)

17. Voiskounsky AE. Flow Experience in Internet mediated environments. In: Leontiev DA, editor. Motivation, consciousness and self-regulation. NY.: Nova Science; 2012.

18. Voiskounsky AE. Flow Experience in Cyberspace: Current Studies and Perspectives. In: Barak A, editor. Psychological aspects of cyberspace: theory, research, applications. Cambridge: Cambridge University Press; 2008.

19. Cash H, D. Rae C, H. Steel A, Winkler A. Internet Addiction: A Brief Summary of Research and Practice. Current Psychiatry Reviews. 2012;1;8(4):292-298.

20. Przybylski AK, Przybylski CS, Rigby RM. A motivational model of video game engagement. Review of General Psychology, 2010;14:154-166. doi:10.1037/a0019440

21. Ryan R, Rigby C, Przybylski A. The motivational pull of video games: A self-determination theory approach. Motivation and Emotion, 2006;30:344-360. doi:10.1007/s11031-006-9051-8

22. Young KS. Caught in the Net: How to Recognize the Signs of Internet Addiction and a Winning Strategy for Recovery. NY: John Wiley Sons; 1998.

23. Zenhausen B. Preliminary Draft of the DSM-V Committee on Cyberdisorders. Posted to Listserv: Virtpsy; 1995.

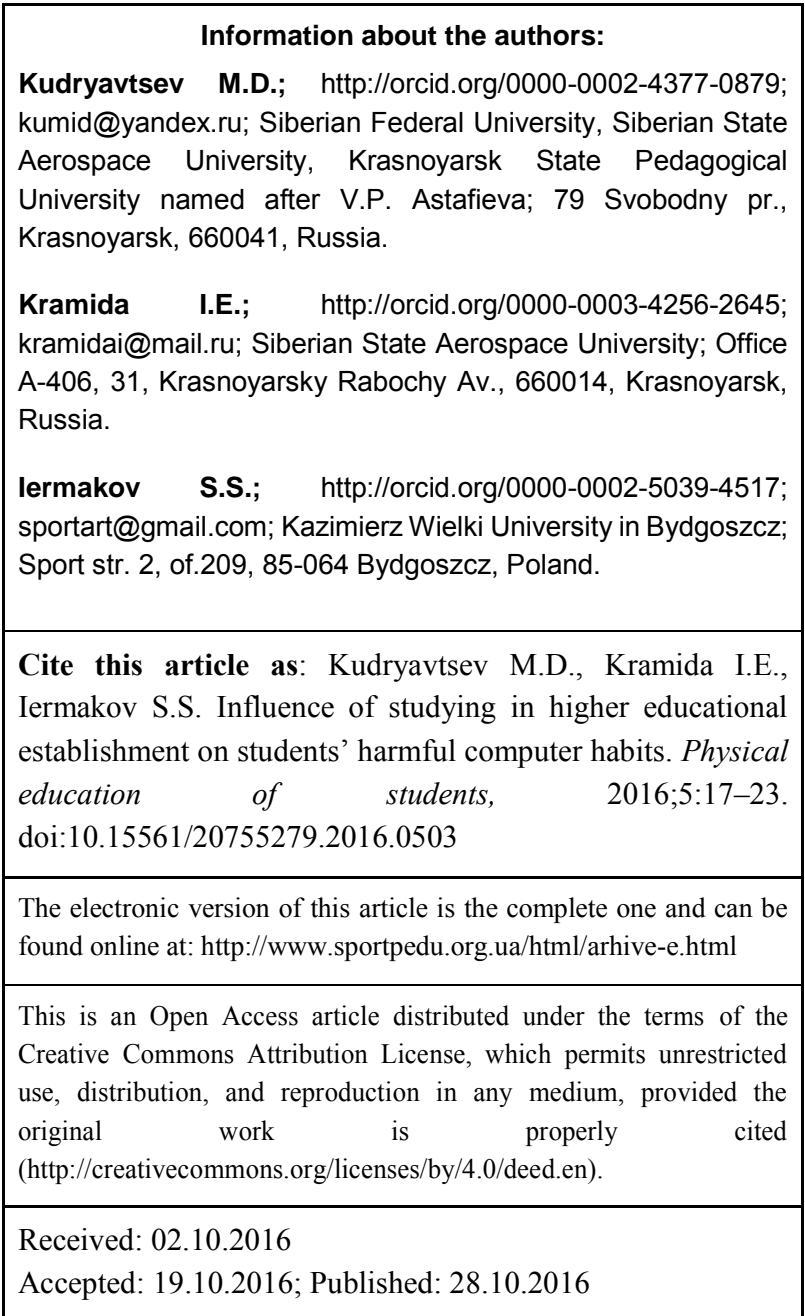

